\title{
Ausztenites korrózióálló acélok lézersugaras vágása
}

\section{Laser Cutting of Austenitic Corrosion-Resisting Steels}

\author{
Halász Gergely, ${ }^{1}$ Fábián Enikő Réka, ${ }^{2}$ Kuti János ${ }^{3}$ \\ Óbudai Egyetem, Budapest, Magyarország \\ 1 gerryhalasz@gmail.com \\ ${ }^{2}$ fabian.reka@bgk.uni-obuda.hu \\ ${ }^{3}$ kuti.janos@bgk.uni-obuda.hu
}

\begin{abstract}
Nowadays, laser technology has become an essential part of our lives. The great advantage of lasers used in materials processing is that they provide very precise, quick machining and low heat input. However, all machining requires unique parameters. These parameters are for example: Power, wavelength, cutting speed and focus line distance. Using optical microscopes and electron microscopes to examine the cutting surfaces of the $\mathrm{CO}_{2}$ laser, we can see that the cut has high quality surface (cutting 3,25 mm thick plates), but holes made with a solid-state laser have micro-cracks on the inner side. These cracks are not acceptable to the customers.
\end{abstract}

Keywords: laser cutting, austenitic stainless steel, $\mathrm{CO}_{2}$ laser, solid-state laser.

\section{Összefoglalás}

Az ausztenites korrózióálló acélok koronglézersugaras berendezéssel való vágása nagyobb anyagvastagság mellett nem teljesen kidolgozott. Kutatásainkban 3,25 mm vastagságú korrózióálló acélon létrehozott furatok felületét vizsgálom $\mathrm{CO}_{2}$-lézerberendezéssel és koronglézersugaras berendezéssel vágva. Fénymikroszkópos és elektronmikroszkópos vizsgálatokkal ellenőrizve a vágási felületeket azt tapasztaltuk, hogy $\mathrm{CO}_{2}$-lézerrel vágva a korrózióálló ausztenites lemezeken jó minőségű vágási felület keletkezik, azonban szilárdtestlézerrel vágott furat belső felületén mikrorepedések jelentek meg, melyek nem megengedhetők.

Kulcsszavak: lézersugaras vágás, ausztenites acél, $\mathrm{CO}_{2}$-lézer, szilárdtestlézer.

\section{Bevezetés}

A 20. század egyik nagy vívmánya a lézer felfedezése volt, mely új távlatokat nyitott számos tudományágban. Az anyagmegmunkálás területén alkalmazott lézerek nagy előnye a többi eljárással szemben, hogy nagyon pontos, gyors megmunkálást és csekély hőbevitelt biztosít, azonban minden megmunkálás egyedi paraméterek beállítását igényli. Ilyen paraméterek például: a teljesítmény, hullámhossz, vágási sebesség, fókusztávolság. $\mathrm{A} \mathrm{CO}_{2}$-lézerrel végzett vágásokkal számos kutató foglalkozott. Az ausztenites korrózióálló acélok lézersugaras vágása bizonyos vastagság fölött nem teljesen kidolgozott. Az utóbbi években a szállézerek teljesítményének erőteljes növelésével sikerült nagy vastagságú korrózióálló acéllemezt elvágni, Seon és társai 9 kW-os szállézerrel 60 mm-es vastagságot sikerült elvágni, de a felület nagyon salakos [1]. Külön problémát jelent a vastag acélok ívelt vágása [2, 3]. Berkmanns és Faerber a teljesítmény mellett az íveltség hatását is vizsgálja a vágott felület minőségére [2]. Parthiban és társai vágással megfelelő minőségű ívelt felületet 2,5 mm vastagságú, X5CrNi18-10 típusú anyagon $\mathrm{CO}_{2}$ típusú lézersugaras berendezéssel tudtak elérni [3].

Kotadiya és társai tanulmányozták a lézersugaras vágás paramétereinek hatását a felületi érdességre. A szerzők úgy találták, hogy $\mathrm{CO}_{2}$-lézersugaras berendezésnél mind a teljesítmény, mind a gáznyomás jelentősen befolyásolja a felületi ér- 
dességet [4], míg szállézersugaras berendezésnél a lézersugár-teljesítmény és a vágási sebesség a meghatározó az általunk is vizsgált korrózióálló acéloknál [5].

A lézersugárral vágott furatok felületének minőségi követelményei az alkatrészek felhasználásának függvényében változik. Az általunk vizsgált alkatrészeknek igen szigorú követelményeknek kell megfelelniük, mert a továbbiakban gázturbinákban lesznek alkalmazva. A vágásokat $\mathrm{CO}_{2}$-lézerrel és szilárdtestlézerrel végeztük el. A $\mathrm{CO}_{2}$-lézernél korábban a cég által jóváhagyott referenciaparamétereket használtunk, míg a szilárdtestlézernél általunk választott paraméterekkel dolgoztunk, mivel a folyamatváltozók megfelelő értékei még nincsenek kidolgozva. A $\mathrm{CO}_{2}$-lézeres vágásnál a vágási rés felülete megfelelt az előírtaknak, azonban a szilárdtest-lézeres vágást tekintve a repedések száma meghaladta a megrendelő által megszabott maximális repedésmennyiség értékét. A kutatásunk célja a próbavágások alkalmával készített furatok felületének vizsgálata és a beállított paraméterek értékelése.

\section{A lézer}

A lézert sugárzásként tekintve annak alapja a stimulált emisszió, amely a lézermédiumban megy végbe, amikor egy, már gerjesztett állapotban lévő atomot egy újabb foton talál el, és az érkező foton magával ragadja a gerjesztett atom addig fogott fotonját, s közösen, az érkezés irányával párhuzamosan haladnak tovább. A lézersugár a rezonátorban jön létre; itt található a lézermédium, a gerjesztő, a záró és féligáteresztő tükör. A médium lehet szilárd, folyékony vagy gáz közeg is. A stimulált emisszió alapfeltétele, hogy több atom legyen gerjesztett állapotban, mint nem gerjesztett állapotban, ezt nevezzük populációinverziónak [6].

\subsection{A szén-dioxid-lézer}

$\mathrm{Az}$ iparban az egyik legelterjedtebb lézerberendezés a $\mathrm{CO}_{2}$-lézer, amit elsősorban vágásra és hegesztésre használtak. Az elsők között alkalmazott, nagy teljesítményü, ipari célra használt lézerek $\mathrm{CO}_{2}$-lézerek voltak. A lézermédium ebben az esetben gázkeverék, mely kvarcüveg csövekben áramlik. A csöveken kívül elektródák segítségével gerjesztik a gázt érintkezés nélkül. A felhasznált lézergázt szén-dioxidból, héliumból és nitrogénből keverik megfelelő arányban. A keletkező lézersugár/lézersugárzás hullámhossza $\lambda=10,6 \mu \mathrm{m}$ [7] .

\subsection{A szállézer}

A szállézer egy összetett, de mégis igen hatékony szilárdtestlézer; a rúdlézerek kedvezőtlen gerjesztési tulajdonságainak megkerülése végett hozták létre. Szilárdtestlézernek minősül, hiszen a lézermédium itt is szilárd, ritkaföldfémmel adalékolt kvarcüveg, amelyben az ionrácsba juttatott idegen atomok gerjesztésével hozzák létre a nagy teljesítményű lézersugarat. A médium egy vékony üvegszál, amely 8-10 $\mu$ m átmérőjü. Ennek a belső magnak a legnagyobb a törésmutatója, ezt veszi körül egy bevonat, amelynek a törésmutatója kisebb. A bevonatban halad a gerjesztést végző, kis teljesítményű lézersugár, amely diódalézerből származik. Az úgynevezett külső köpeny, melynek a törésmutatója a legkisebb, gondoskodik arról, hogy a gerjesztést végző lézer ne jusson ki. A gerjesztő lézersugárzás könnyedén belép a magba, azonban kilépni már nem tud ilyen könnyen, az indukált emisszióval létrehozott nyalábnak pedig szinte lehetetlen kijutnia. A sugár visszaverésére itt zárótükrök helyett úgynevezett Bragg-rácsot alkalmaznak, amelyet a szál magjának két végén hoznak létre az optikai tengelyre merőlegesen. Ezekben a sávokban (rácsvonalakban) a törésmutató különbözik a mag törésmutatójától, és a sávok periodikusan változó vastagságúak [7].

\subsection{A koronglézer}

A koronglézernél a hajszálvékony szál helyett lapos, vékony, kör alakú korongot használnak lézermédiumnak. A gerjesztő diódalézerből származó lézersugarat tükrök segítségével többször átvezetik a lézermédiumon, így populációinverziót idézve elő. A gerjesztett lézernyalábot ezután kivezetik, és optikai kábellel vezetik a megmunkálás helyére. Az így előállított sugárzás sugárminősége eléri a $\mathrm{CO}_{2}$-lézerét, és nagyobb hatékonyságot biztosít. Ezzel együtt a koronglézernek is megvan a szállézer nagy előnye: optikai kábellel továbbítható a lézersugár. A koronglézer hullámhossza $\approx 1 \mu \mathrm{m}$, ami azt jelenti, hogy egy nagyságrenddel kisebb, mint a $\mathrm{CO}_{2}$-lézernek [7]. Ez fontos szerepet játszik a hőbevitel szempontjából, és az elvégzett vizsgálatok eredményét döntően befolyásolja. A technológiai változók alkalmazott értékeit ehhez mérten állítottuk be.

\section{A kísérletek ismertetése}

A vizsgált anyag X5CrNi18-10 típusú, ausztenites korrózióálló acél. A próbavágásokat 3,25 mm vastag lemezen végeztük el. Az első referenciavágás TruFlow 4000 típusú, 4 kW-os szén-dioxid-lézer- 
rel, a további vágások pedig Tru-Disk 3000 típusú, 3 kW-os koronglézerrel készültek.

A furatfelületet elsőként szemrevételezéssel vizsgáltuk a vágások után közvetlen, majd a furatok belső felületét és a peremét Dino-Lite Digital hordozható fénymikroszkóp segítségével. A lézervágott felületek részletes vizsgálatát, esetleges hibáit Jeol JSM 5310 típusú pásztázó elektronmikroszkóppal (SEM) tártuk fel.

\section{Vizsgálati eredmények}

Először egyszerű, hordozható fénymikroszkóp segítségével készítettünk képeket a furat felületéről, hogy a későbbi vizsgálatoknak tudjunk alapot adni. Ezeken a képeken jól látszik a lézersugár ki- és belépési pontja, a fókuszfolt helye és a peremeken a fröcskölés, továbbá a furat alsó peremén látható az úgynevezett tapadósalak, ami az alapanyaghoz kötődő vas-oxid , azonban repedések ezeken a képeken nem láthatók.

$\mathrm{Az}$ 1. ábrán jól látható tapadósalak a furat peremén jellegzetesen a $\mathrm{CO}_{2}$-lézerrel vágott mintadarab felületén látszódott. Ezeknél a vágásoknál a cég által korábban elfogadott referenciaparamétereket használtam, melyeket már meglévő alkatrészek gyártására alkalmaznak. A metallográfiai $40 \mu \mathrm{m}$ körüli egyenletes megolvadt zónát mutat (2. ábra), amely helyenként

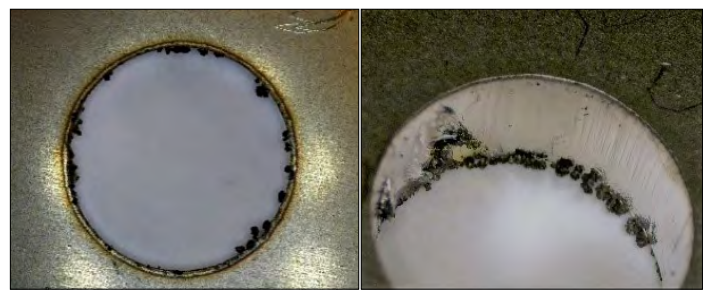

1. ábra. Visszatapadó vas-oxidok $\mathrm{CO}_{2}$-lézerrel vágva ( $\phi 6,2$ furat)

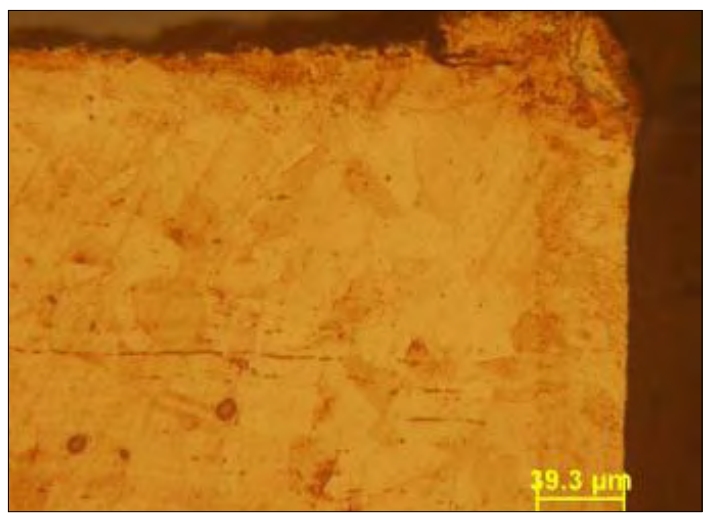

2. ábra. A furat felülete közeli zónája $\mathrm{CO}_{2}$-lézersugaras vágás után. Marószer: királyvíz közel azonos mértékben túlfolyva dermedt meg a vágás irányának megfelelően.

Ezzel szemben a koronglézerrel vágott daraboknál ilyen mértékű visszatapadó salak nem jelentkezett. Első ránézésre és tapintásra a furat pereme durva, azonban a belső felületének érdessége megfelelő.

A referenciavágás után következtek a vágások koronglézerrel. A próbavágások során az energiabevitel csökkentésével változtattuk a paramétereket. Különböző sebességgel és energiával készítettük el a 3. ábrán látható furatokat. A jóval kisebb hullámhossz miatt az anyagban elnyelt hő nagyobb volt, mint azonos paraméterek alkalmazásánál $\mathrm{CO}_{2}$-lézernél, ezért érezhetően gyorsabb volt a koronglézerrel való vágás. Termelékenység szempontjából ez igen fontos. Az elkészült darabokon elsőre jól látható, hogy a furatperem felületi érdessége jobb, a szemrevételezéses vizsgálat során a darab minősége a referenciadarab felületi minőségét is felülmúlta. Egyes paramétereknél azonban itt is volt fröcskölés.

A 4. ábrán jól látható a furat felületének minősége, sem fröcskölés, sem pedig visszatapadt

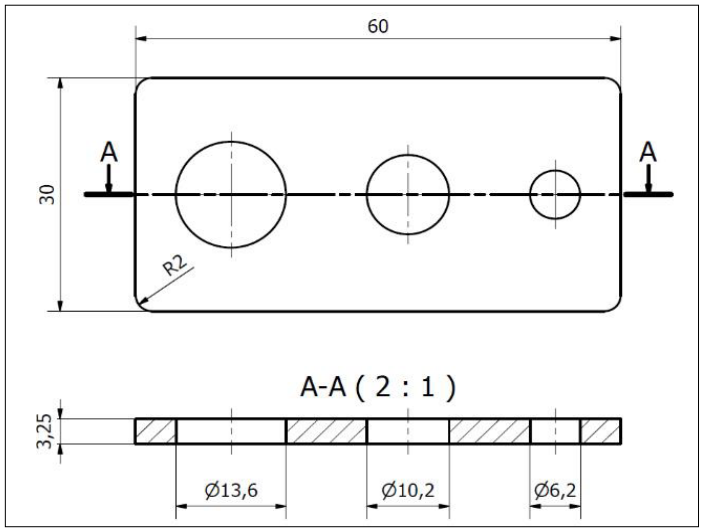

3. ábra. A koronglézerrel készített mintadarab geometriája

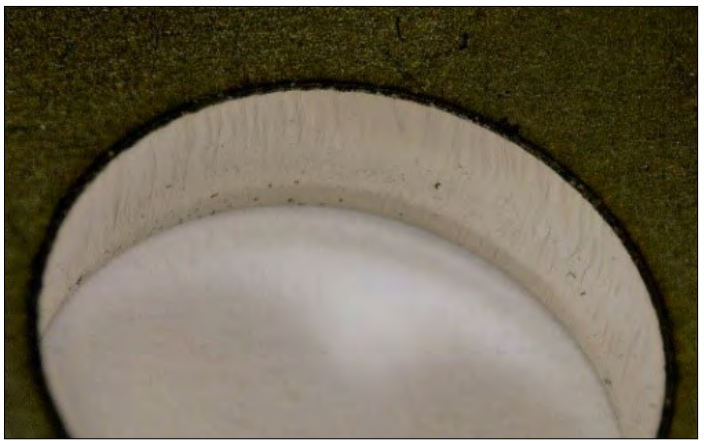

4. ábra. Koronglézerrel készült furat ( $\phi$ 13,6 furat) 


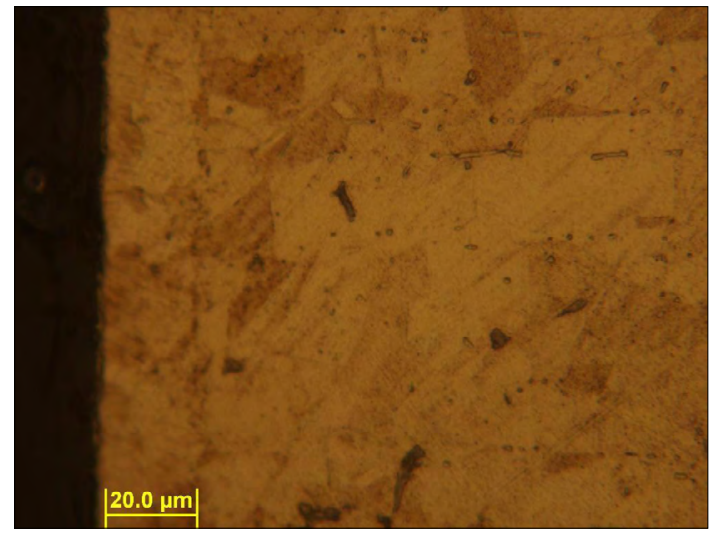

5. ábra. Koronglézerrel vágott furat olvadékzónája

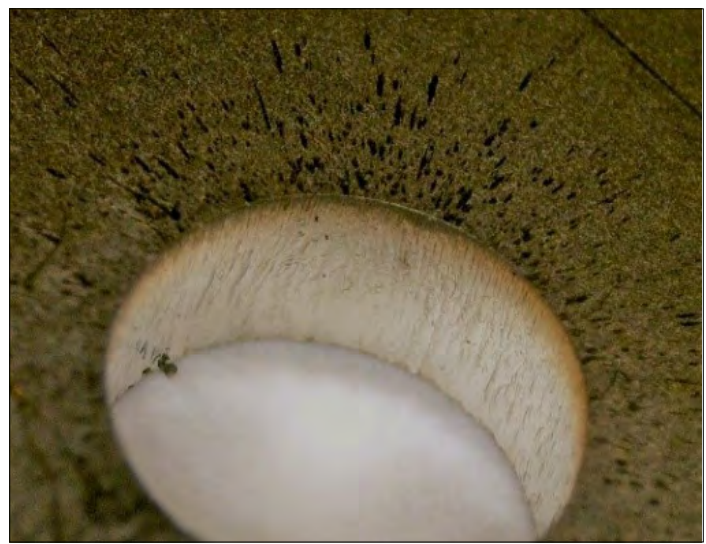

6. ábra. Fröcskölés a koronglézerrel vágott furat pereménél ( $\phi$ 6,2 furat)

salak nem tapasztalható. Az olvadékréteg vastagsága a megadott $60 \mu \mathrm{m}$ megengedett érték alatt van. Ezt igazolja a furatról készült metallográfiai kép is, amely az 5 . ábrán látható.

Szemrevételezés során a furat pereme és felülete is megfelelö, azonban csökkentett teljesítmény mellett megjelent a fröcskölés. A kisebb teljesítményen végzett vágások jelentős utómunkával eltávolítható fröcskölést eredményeztek.

A vágógáz nem mindenhol tudta megfelelően kifújni az olvadékot, ami fröcskölést okozott. Ennek eredménye a 6. ábrán látszik. A fókusztávolság változtatásával a furat minőségének drasztikus romlása látható a 7. ábrán. Látszik, hogy a felületi érdessége megnőtt, és fröcskölésből származó olvadék jelent meg a furat és a darab felületén egyaránt.

Összességében kijelenthető, hogy a szemrevételezés és a fénymikroszkópos vizsgálat alapján a koronglézerrel készült furatok többségénél a felületi érdesség kisebb, mint a $\mathrm{CO}_{2}$-lézerrel készült furatoknak, azonban mivel ezek az alkatrészek

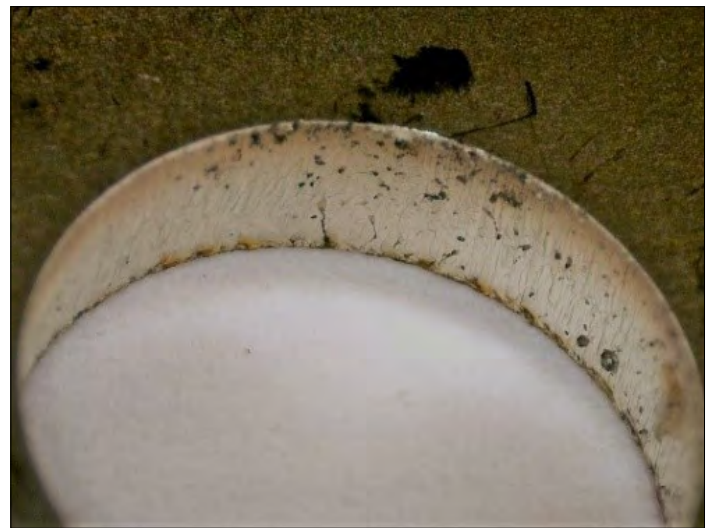

7. ábra. Koronglézerrel készült furat - a fókusztávolság eltért a középvonaltól ( $\phi$ 13,6 furat)

ciklikus hőterhelésnek lesznek kitéve, a felületen nem megengedettek mikrorepedések. Ezért a fénymikroszkópos vizsgálatok eredménye nem bizonyult elegendőnek, hiszen ezekkel a repedések nem kimutathatók, ezért a továbbiakban a jóval nagyobb felbontóképességű pásztázó elektronmikroszkóppal készítettem képeket. A furatokat a lehető legkisebb hőbevitel érdekében vízsugárral vágtuk félbe. A vágott furatok felületét már mikroszkóp alatt tudtuk vizsgálni, amely jóval nagyobb nagyítású és felbontású képek készítésére alkalmas. A nagy felbontás segítségével ezeken a képeken olyan kiválások, repedések és anyaghibák is kimutathatók, amelyek fénymikroszkóp alatt nem láthatók.

Ezeken a képeken már jól látszik, hogy a koronglézerrel készült, kívülről jó minőségű furatok apró, de veszélyes hibát hordoznak. A furat felületén keresztirányban mikrorepedések vannak. Az ilyen hibák ciklikus hőterhelés hatására képesek továbbterjedni, és ez akár az alkatrész tönkremeneteléhez is vezethet. $\mathrm{A} \mathrm{CO}_{2}$-lézer által készített furatokban is találtunk repedést, azonban ezek mennyisége annyira csekély, hogy a megrendelő által előírt tűrésmezőn belül van. A koronglézer esetében viszont a repedések mennyisége a $\mathrm{CO}_{2}$-lézer esetében elfogadott érték felett van, így ezek a furatok nem felelnek meg. A 8. ábrán jól kivehető, hogy viszonylag sok repedés látható a lézervágáskor megolvadt furat felületén, melyek mind keresztirányban helyezkednek el, sokszor a lemezvastagság közepénél.

A repedések hosszúságának és szélességének meghatározására nagyobb nagyításban is készítettem képeket. A 9. ábrán jól látszik, hogy a repedések hossza 30-80 $\mu$ m között mozog, szélességük pedig $2-4 \mu \mathrm{m}$. 


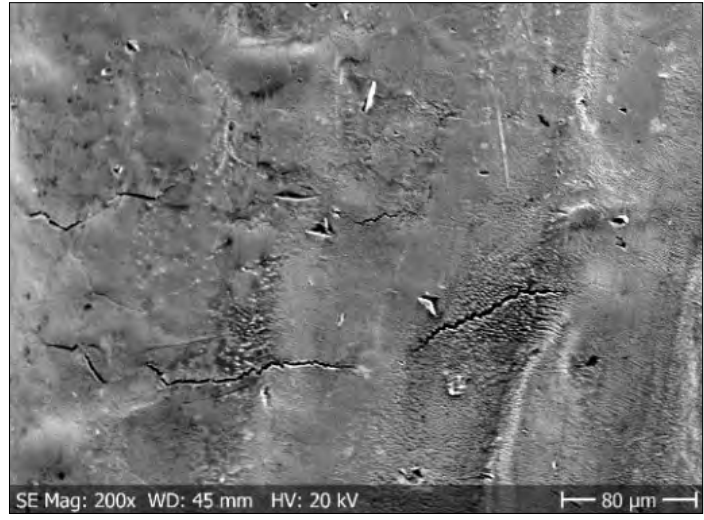

8. ábra. Repedés a furat felületén koronglézerrel való vágás után (SEM-felvétel)

Az elektronmikroszkóppal vizsgált furatokról készült képeken végig hasonló tendencia mutatkozik meg, a repedések hossza 30-100 $\mu$ m között mozog, szélességük pedig 2-4 $\mu \mathrm{m}$. A repedések mélysége azonban a mikroszkópos képek alapján nem állapítható meg. A vizsgálatok egyelőre csak a $\mathrm{CO}_{2}$-lézer által végzett vágásokra és a koronglézer egyik változójára terjedtek ki. A további folyamatváltozók részletes roncsolásos anyagvizsgálatára is sor fog kerülni.

A meglévő adatok alapján és a szakirodalom segítségével következtetni tudok a repedések okára.

A szakirodalmi adatok a lézerrel vágott felületeken megjelenő repedések egyik lehetséges okaként alapanyag hengerlése során kialakult rétegződéseket nevezik meg, ami magyarázná a furatokban a vágásra merőleges, keresztirányú repedéseket. Azonban nagyítás mellett láthatóvá vált, hogy a repedések alapvetően töredezettek (8-9. ábra), és a koronglézeres vágásnál nincsenek bizonyos zónához kötve, hanem a furat teljes felületén szétszórtan megjelennek, ezért ennek az opciónak kicsi a valószínűsége.

A második lehetőség az úgynevezett likvációs repedés. E témával Lippold [8, 9] foglalkozik behatóan. Az erősen ötvözött anyagokban hegesztés vagy vágás során a részben megolvadt zónában kialakulhatnak az alapanyag-összetételtől függően különböző karbidok. Ezeknek a karbidoknak, mint amilyen a nióbium-karbid, titán-karbid vagy króm-karbid, nagyobb az olvadáspontja, mint az őket körülvevő anyag, ezért a részben megolvadt zónában a karbidok nem olvadnak meg, és ezek az ömledék szilárdulásakor repedéseket okoznak, viszont az általunk vizsgált anyagban sem $\mathrm{Nb}$, sem Ti nincs. Króm-karbid-kiválás megjelenhet, mint az 5. ábra jobb szélső repedése, de jellemzően a repedéseknél karbid jelleget nem sikerült ki-

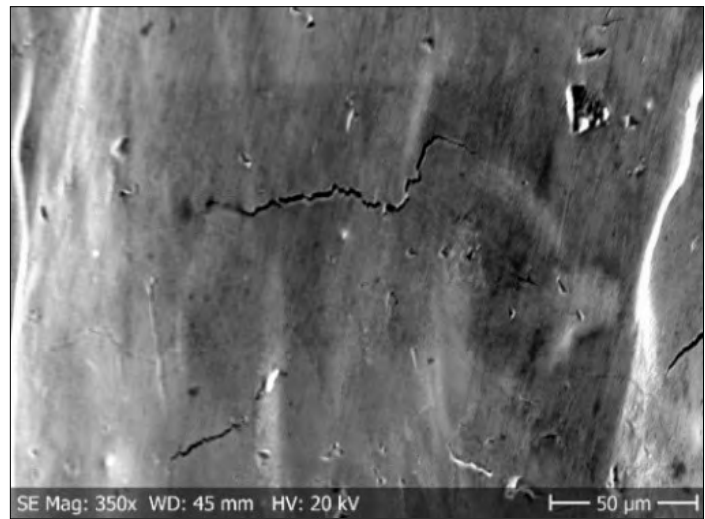

9. ábra. Repedés a furat felületén koronglézerrel való vágás után (SEM felvétel)

mutatni. Ausztenites acéloknál, ha a varrat ferrittartalma eléri az 5-10\%-ot, általában nem jelentkeznek repedések, ha nem túl nagy a hőbevitel és nem konkáv a felület [10], de a mi mintáinknál sajnos nincs hozaganyag, konkáv a felület, nagy a hőbevitel és a koronglézeres vágásnál nitrogént használunk, ami ausztenitképző.

\section{Következtetések}

Az elvégzett vizsgálatok alapján kijelenthető, hogy a koronglézerrel készült furatok szemrevételezéssel láthatóan jobb minőségűnek bizonyultak, az olvadékzóna vastagsága $40 \mu \mathrm{m}$ alatt volt az összes mintadarabnál, repedést azonban nem találtunk a metallográfiai vizsgálatok során. A $\mathrm{CO}_{2}$-lézerrel készült darab felülete és pereme kevésbé volt jó minőségű, azonban a furat felületén mikrorepedések nem találhatóak. Annak ellenére, hogy szemrevételezésnél rosszabb minőségűnek tűnik, a furat felületén sokkal kevesebb a repedés. A fröcskölés és a visszatapadó salak minimális utómunkálással eltüntethető.

Koronglézer használatakor, paraméter-változtatások segítségével csökkenthető a hőbevitel, amivel jobb felületi minőséget tudunk elérni, ám a mikrorepedések mennyiségének vizsgálata a változtatott paraméterek hatására további vizsgálatokat igényel. Jelen vizsgálatok alapján úgy találtuk, hogy ipari alkalmazásra a $\mathrm{CO}_{2}$-lézer által készített alkatrészek használhatók a jelen paraméterekkel.

\section{Köszönetnyilvánítás}

A szerzők ezúton kívánnak köszönetet mondani a munkánkhoz nyújtott anyagi támogatásért az EFOP-3.6.1-16-2016-00010 számú projekt keretében a magyar államnak és az Európai Uniónak. 


\section{Szakirodalmi hivatkozások}

[1] Seon S., Shin J. S., Oh S. J., Park H., Chung C.-M., Kim T.-S., Lee L., Lee J.: Improvement of cutting performance for thick stainless steel plates by step-like cutting speed increase in high-power fiber laser cutting. Optics and Laser Technology, 103. (2018) 312-317. https://doi.org/10.1016/j.optlastec.2018.01.054

[2] Berkmanns J., Faerber M.:Facts about laser cutting. Linde AG Linde Gas Division, Höllriegelskreuth www.laserdeal.com/techInfoFiles/_FactsAbout_ LasertBasics.pdf

[3] Parthiban A., Chandrasekaran M., Muthuraman V., Sathish S.: Optimization of $\mathrm{CO}_{2}$ Laser Cutting of Stainless Steel Sheet for Curved Profile, ICAFM, 2017. 14531-14538.

https://doi.org/10.1016/j.matpr.2018.03.042

[4] Kotadiya D. J., Pandya D. H.: Parametric analysis of laser machining with response surface method on SS-304. ICIAME, 2016. 376-382.

https://doi.org/10.1016/j.protcy.2016.03.040
[5] Kotadiya D. J, Kapopara J. M., Patel A. R., Dalwadi C. G., Pandya D. H.: Parametric analysis of process parameter for Laser cutting process on SS-304. ICMPC, 2017. 5384-5390. https://doi.org/10.1016/j.matpr.2017.12.124

[6] Buza G.: Lézersugaras technológiák I. Edutus Főiskola, Budapest, 2012. 4-65.

[7] Leibinger-Kammüller N.: The Laser as a tool. TRUMPF GmbH + Co., Ditzingen, 2007.

[8] Lippold J. C.: Welding Metallurgy and Weldability. John Wiley \& Sons, Inc., Hoboken, NJ, 2015. 119-130.

[9] Lippold J. C., Kotecki D. J.: Welding Metallurgy and Weldability of Stainless Steels. Wiley, Hoboken, 2014.

[10] Shields J., Kovach C. (szerk.): Practical Guidelines for the Fabrication of High Performance Austenitic Stainless Steels. International Molybdenum Association (IMOA), London és International Chromium Development Association (ICDA), Paris, 2010.

https://www.imoa.info/download_files/stainless-steel/Austenitics.pdf 